Europe's J oumal of Psychology 2/2009, pp. 64-81

www.ejop.org

\title{
Expression of Aggressive Tendencies in the Drawings of Children and Youth Who Survived the Northem Pakistan Earthquake
}

\author{
Zainab Fotowwat Zadeh \\ Ba hria University \\ Sonia Ma iraj Malik \\ Ba hria University
}

\section{Abstract}

The study focused on the presence of aggressive tendencies in the drawings of children who survived the northem Pakistan earthquake. The data was collected one year after the earthquake from Sahara Children Academy (Mallot Tehsil) and Surbuland (camp school set up by the Amy at District Bagh). The sample consisted of 75 children ( 44 boys and 31 girls) age range from 5 to 15 years with a mean age of 8 years. The Human Figure Drawing as projective test (Koppitz, 1969) was used. The drawings were analyzed utilizing a list of emotional indic ators for aggression. The list, consisting of 24 indicators, was drawn from the literature on assessment of human figure drawings (Gilbert, 1980). The results indicated the presence of aggressive tendencies a mong these children with straight lines as the most frequently occurring indicator among both genders. Chi square analysis was conducted to compare males and females for the frequency of occurrence of emotional indicators in drawings. Findings reflect significant differences in frequency of occurrence of aggression related indicators between genders with calculated $X^{2}=4.37, p<05$. However, there was no significant difference observed with reference to the content of emotional indic a tors for boys and girls.

Introduction

Natural disasters such as earthquakes, floods and storms may produce psychological trauma which has profound effects on the intrapsychic, interpersonal, emotional, social, intellectual and neurologic al development of children and youth. The effects of these traumatic events on the psyche of the child depend on his age, 
developmental stage, family and cultural milieu. Most of the children will be able to cope over time with the help of parents and other caring adults. However, some children may be at risk of extreme reactions. The severity of children reactions will depend on their specific risk factors. These include exposure to the actual event, personal injury or loss of a loved one, dislocation from their house or community, level of parental support, the level of physical destruction, and preexisting risks, such a previous traumatic experiences and mental illness (Hussa in, 2005). Elementary school children and adolescents may show symptoms like imitability, aggressiveness, clinginess, nightmares, school avoidance, poor concentration, and withdrawal from activities and friendships, sleeping and eating disturbances, agitation, increase conflic ts, physical compla ints and delinquent behavior (Lazarus, J imerson and Brock, 2002).

Trauma can be connected with anger in many ways. After experiencing trauma people often feel that the situation was unfair or unjust. The individual cannot comprehend why the event has happened and why it has happened to him. This thought can result in intense anger. Although anger is a natural and healthy emotion, intense feeling of anger and aggressive behavior can cause leaming and relational problems (Gardner 1971, Parson 1994).

Aggression can be studied in many ways. One of the ways employed to measure aggressive responses is through the Human Figure Drawing test. Lowenfeld (1947) has claimed that children exaggerate the size of dra wings for topics which a re important to them. A number of studies have been conducted to assess sex differences on different variables. Aggression is the most popular field in this respect. Elaenor Maccody and Carol Jackelin (cited In Zafran \& Zawitz, 1997) observed obvious differences in aggressive behavior, with males showing more aggression than females. On human figure drawings at all age levels, there appear to be some drawing items which are more masculine orfeminine and which occur more often in the human figure drawings of boys or girls respectively. Masculine items include profile drawing, ear and knee while feminine items include, hair, pupils, eyebrows, two lips and clothing ( Koptiz, 1969).

Naumburg's (1958) disc ussion of the famous study of the children of Terezin, shows how art is used to overcome the catastrophic stressor of a concentration camp. It stresses the importance of being able to use non-verbal communication to express emotions. Many clinicians use a projective drawing task as it is an "ice breaker" and an easy way to engage kids. Drawings of children were studied after the 9/11 attack and it was found that children were expressing heightened states of fearby drawing 
aimplanes crashing into buildings. Perhaps the friendliest of all psychological tools, drawing and story making tasks are especially suitable when dealing with children. They talk while they draw and express their feelings through this simple task, with or without colors. The basic assumption is that the child projects things onto the drawings that by this come to talk about him. Moreover, children try to make sense of the event by discussing their pictures and try to correct the event by drawing patriotic symbols (Myers, 2002).

Machover (1949) was among the first clinicians to be interested in the Human Figure Drawings as a projective instrument, focusing on how the drawings reflected the anxieties, impulses, self-esteem, and personality of the test taker. Many studies have been conducted using the human figure drawings in the diagnosis of psychoses, symptoms of anxiety, depression and schizophrenia (Deslauriers \& Halpem, 1947, Baldwin 1964, Arieti, 1974).

DiLeo, (1973) a fter using the human figure drawing effectively in many researches came to various conclusions:

- Drawing by well adjusted children are 'strikingly similar', and those drawings done by the emotionally disturbed children are 'strikingly different' from the well adjusted children's drawings and from each other, 'as each child is disturbed in his own special way'.

- As a projective test he enumerates a number of signs on the Human Figure Drawing test that can be indic ators of feelings and personality traits. This test also is an indic a tor of sec urity and insec unity for exa mple insec ure children can draw small figures. Maladjusted children tend to omit a ms, hidden hands are considered as an expression of guilt. This test was also used by him as an indicator of aggressive tendencies which are shown by the exaggerated size of hands. In case the exaggerated size of hands is portrayed in the self figure the drawing indicates aggression towards another. But when the same drawing of exaggerated drawing is portrayed in the figure of parents it indicates aggression incurred by the patient from the environment. He also concludes that an explicit manifestation of genitals in the human figure drawings is and indic a tor of behavior disorders, aggression and phobias.

- He claimed that drawings of the family can be an aid to assess the emotional life of the child. This is especially true for children who are going through the latency period i.e. younger children ranging from age 6 to 10 years who are not willing or able to give verbal expression to their emotional conflicts, thus becoming imperative to ask them to draw a fa mily figure. The indic ators of the family relationship - for example, omission of a family member, omission of self, 
relative position, similarly relative size, role in the family interaction and isolation - all these become a valuable aid in the interpretation of the child's psychopathology.

Moreover, Daum (1983) explored the level of association between a feature in a drawing and a behavioral or personality trait. In this study the human figure drawings of 200 aggressive or withdrawn male delinquents were evaluated and compared with both undifferentiated delinquents and non delinquents with the expectation that the former groups would show a higher incidence of those features which have been associated with these respective traits. Signific ant differences were found for 6 of the 16 features, and predictive power was substantially increased by using all the features as ind ic ators of their respective tra its.

Glazer (1999) describes art as having an inherent therapeutic value, constituting the symbolic speech of suppressed feelings. Stronach-Buschel (1990) explains that art therapy is described as a method of non-verbal communication, for example a child drawing a picture to express his or her emotions.

Furthemore, the Human Figure Drawing test is also used in the educational and clinic al settings. One of the most attractive features of this projective measure is the near universality of drawing. It is easy to administer with reasonable standardization in a wide variety of age and cultural groups. The fact the response is not mediated by language suggests that the technique may be less subjective to cultural and age limits than many other projec tive techniques. It can be administered ind ividua lly or in a group condition. It can be administered in a brief period of time. The purpose of the test is well cloaked from all but the most sophistic ated subjects. Thus it is not easy for the subjects to create a desired impression (Lindzey, 1961).

Sundberg (1959) used a survey to detemine which tests were mostly used by the psychologists in their c linic al work and found that Human Figure Drawing test ranked two after Rorscach among all the 62 projective and objective diagnostic tests reported in the survey.

However the Human Figure Drawing test utilization in a clinical context has dropped to fifth from second and the terms "objective test" and "projective test" have recently come under criticism in the Joumal of Personality Assessment (Klopfer, Taulbee, 1976). There remain some controversy regarding the utility and validity of projective testing which is based on Freud's concept of projecting one's own personality 
attributes onto a neutral stimulus. However, many practitioners continue to rely on projective testing.

Human figure drawings have become a popular mode of child assessment, along with numerous systems for interpretation of the drawings, due to time economy, ease of administration, and the clinical infomation provided, and are widely used cross-culturally to evaluate personality by anthropologists and social psychologists (Dennis, 1966, Gardiner, 1969, Gonzales, 1982).

Considering the fact that there is dearth of all kinds of psychological tests in Pakistan, the Human Figure Drawing test was especially chosen as the interpretation noms for this test have been already established in Pakistan (Hasan \& Ahmad, 1990). Utilizing Koppitz's (1969) method, the test was found to be highly valid as a measure of emotional indicators (El) when correlated with the ratings of the teachers on the Kopptiz questionnaire for the measurement of emotional problems. The study also indic ated that the cut off point is three emotional indicators (per drawing, out of 30 emotional indicators) in Pakistan instead of a point of two emotional indicators in the advanced countries. The findings of the study also showed a cluster of frequent and rare emotional indic a tors for the Pakistani culture.

Furthermore, in a study conducted by Bano, Irshad \& Ahmad (2004) on the Afghan refugee children Human Figure Drawing test (HFD) was used to tap aggression as an emotional indicator reflected in the drawings. The findings of the study indicated the frequency of occurence for specific indicators related to aggression among refugee children; differences between males and females were also reported. Moreover, a list of emotional indicators containing 24 aggression indicators was utilized in this study for a nalyzing the drawings, this list was drawn from the literature on drawings a nalysis (Gilbert, 1980), and the exact same list was used in the present study for scoring and analyzing the drawings.

Marsee (2008) conducted a study to explore the association between exposure to Huric ane Katrina and reactive aggression via post traumatic stress disorder (PTSD) symptoms and poorly regulated emotions. In this research 166 adolescents (61\% female, 63\% Caucasian) recruited from high schools of Gulf Coast of Mississippi participated in the study.

The present study explores the psychological after effects of the earthquake that shook the Northem Region of Pakistan. The earthquake of 8th October 2005 in the Northem Regions of Pakistan left 2.8 million homeless, more than 80,000 dead, and 
an equal number injured. It destroyed 0.2 million houses (Akhtar, Anwar, Khan., Noshab, Sa diq, Bashir, and Samar, 2006).

The study aims at scientifically analyzing the presence of aggressive tendencies in the drawings of the children who survived the Northem Pakistan earthquake. Furthemore, it focuses on a theoretical model illustrating a potential pathway to reactive aggression through exposure to a traumatic event. In light of the current literature it was assumed that the drawings of children and youth effected by the Northem Pakistan earthquake will exhibit aggressive tendencies.

Method

Partic ipants

The sample consists of 75 children ( 44 boys and 31 girls) a ge range from 5 to 15 years. The students were studying at the Sahara Children Academy (Mallot Tehsil) and Surbuland (camp school set up by the Army at District Bagh).

Materials

The material included the Human Figure Drawing test (Koppitz 1969); a list of 24 aggression indicators utilized by Bano, Irshad \& Ahmad (2004) was used in the present study (this list was drawn from the literature for analyzing by Gilbert, 1980). Human Figure Drawing test as a projective test was used in the present study as the use of language is at its minimum and simple instructions are given by the examiner during the test administration, therefore it is easier to translate them into Urdu or any other regional language of Pakistan without changing the spinit of the real test.

List of emotional ind ic a tors (G ilbert, 1980)

\begin{tabular}{|l|l|}
\hline SR.\# & AGG RESSION INDICATORS \\
\hline 1 & Weapons, Knives and Gun \\
\hline 2 & Long a mms extended from body and overlong \\
\hline 3 & Long Ams \\
\hline 4 & Claw Fingers \\
\hline 5 & Hands Emphasized \\
\hline 6 & Long Fingers \\
\hline 7 & Eyes Emphasized \\
\hline 8 & Angular Body \\
\hline
\end{tabular}




\begin{tabular}{|l|l|}
\hline 9 & Ams out with fists clenched \\
\hline 10 & Few curves, Many sharp edges \\
\hline 11 & Figure clothed with toes exposed \\
\hline 12 & Heavy Shading \\
\hline 13 & Large same sex figure \\
\hline 14 & Middle of page dra wing \\
\hline 15 & More than five fingers \\
\hline 16 & Pressure \\
\hline 17 & Shoulders squa red \\
\hline 18 & Straight Lines \\
\hline 19 & Strokes a way from subject \\
\hline 20 & Teeth well-defined \\
\hline 21 & Large figure shifted to left \\
\hline 22 & Chin Enlarged \\
\hline 23 & Spear Fingers \\
\hline 24 & Hands Powerful \\
\hline
\end{tabular}

Procedure

The students were met after a year of the earthquake and were approached in their classrooms.

This time frame was chosen as frequently a person's reactions to tra uma initially meet the criteria for Acute Stress Disorder in the immediate aftemath of the trauma (this lasts for a minimum of two days and a maximum of 4 weeks). Symptoms for PTSD usually begin within the first three months after the trauma; there may be a delay of months or even years before symptoms appears, complete recovery occurs within three 3 months in approximately half of the cases, however, many may have persistent symptoms longer than 12 months after the tra uma (DSM IV TR, 2000). It was therefore the best time to acknowledge that survivors can be involved with the disa ster aftermath even after a yearand identify individuals who were not given any formal diagnosis during the required period but may manifest behavioral problems or vulnerability to emotional issues in future.

Initial rapport was built with them. The students were provided with $8_{1 / 2} \times 11$ inch white paper sheets and the standard instructions for the HFD as given by Koppitz (1969) were communic ated to them, instruction given as follows: "On this piece of paper I would like you to draw a WHOLE person. It can be any kind of a person you 
want to draw, just make sure that it is a whole person and not a stick figure or a cartoon figure". It was ensured that they understood it and drew a whole person.

The drawings were then analyzed for the presence of emotional indicators of aggression as given by Gilbert (1980). The data received was then sorted by gender and age along with the frequency of the aggression indicators. Percentages were calculated for both genders separately as well as by summing up the entire data to find out the occurrence of emotional indic a tors irrespective of gender differences.

Results

The results shown in Table 1 and 2 indicate the presence of aggression indicators in these drawings and verify the association of reactive aggression indicators in the drawings with the history of trauma. The data reports $16.37 \%$ of children drew figures with straight lines (see fig 01), $7.5 \%$ drew claw fingers and reflected pressure (see fig 02). Long arms (see fig 03) were drawn by $7.1 \%$ while $6.63 \%$ drew clothed figure with toes exposed. 5\% drew teeth which were well-defined (see fig 04). 4.86\% emphasized eyes (indicator for aggressive and assault behavior) while $4 \%$ had drawn spear fingers, squared shoulders and long ams extended from body and overlong. None of the drawings revealed weapons, knives and guns.

Table 1. Showing percentage of aggressive emotional indic ators in females

\begin{tabular}{|l|l|l|l|}
\hline SR.\# & AG GRESSION INDICATORS & $\begin{array}{l}\text { RESPONSE } \\
\text { FREQUENCY }\end{array}$ & PERCENTAGE \\
\hline 1 & Weapons, Knives a nd Gun & 0 & 0 \\
\hline 2 & $\begin{array}{l}\text { Long a ms extended from body a nd } \\
\text { overlong }\end{array}$ & 4 & 4.1 \\
\hline 3 & Long Ams & 10 & 10.2 \\
\hline 4 & Claw Fingers & 5 & 5.1 \\
\hline 5 & Hands Empha sized & 5 & 5.1 \\
\hline 6 & Long Fingers & 1 & 1 \\
\hline 7 & Eyes Empha sized & 6 & 6.1 \\
\hline 8 & Angular Body & 5 & 5.1 \\
\hline 9 & Ams out with fists clenched & 2 & 2 \\
\hline 10 & Few curves, Many sha p edges & 8 & 8.16 \\
\hline 11 & Figure clothed with toes exposed & 9 & 9.2 \\
\hline 12 & Heavy Shad ing & 0 & 0 \\
\hline 13 & Large same sex figure & 1 & 1 \\
\hline 14 & Middle of page drawing & 5 & 5.1 \\
\hline
\end{tabular}




\begin{tabular}{|l|l|l|l|}
\hline 15 & More than five fingers & 2 & 2 \\
\hline 16 & Pressure & 3 & 3 \\
\hline 17 & Shoulders squared & 1 & 1 \\
\hline 18 & Straight Lines & 15 & 15.3 \\
\hline 19 & Strokes away from subject & 0 & 0 \\
\hline 20 & Teeth well-defined & 8 & 8.16 \\
\hline 21 & Large figure shifted to left & 0 & 0 \\
\hline 22 & Chin Enlarged & 2 & 2 \\
\hline 23 & Spear Fingers & 3 & 3 \\
\hline 24 & Hands Powerful & 3 & 3 \\
\hline
\end{tabular}

Table 2. Showing percentage of aggressive emotional indic ators in males

\begin{tabular}{|l|l|l|l|}
\hline SR.\# & AGG RESSION INDICATORS & $\begin{array}{l}\text { RESPONSE } \\
\text { FREQUENCY }\end{array}$ & PERCENTAGES \\
\hline 1 & Weapons, Knives and G un & 0 & 0 \\
\hline 2 & $\begin{array}{l}\text { Long ams extended from body } \\
\text { and overlong }\end{array}$ & 5 & 4 \\
\hline 3 & Long Ams & 6 & 4.7 \\
\hline 4 & Claw Fingers & 12 & 9.4 \\
\hline 5 & Hands Emphasized & 2 & 1.56 \\
\hline 6 & Long Fingers & 2 & 1.56 \\
\hline 7 & Eyes Emphasized & 5 & 4 \\
\hline 8 & Angular Body & 9 & 7 \\
\hline 9 & Arms out with fistsclenched & 1 & 0.78 \\
\hline 10 & Few curves, Many sham edges & 4 & 3 \\
\hline 11 & Figure clothed with toes exposed & 6 & 4.7 \\
\hline 12 & Heavy Shading & 7 & 5.5 \\
\hline 13 & Large same sex figure & 2 & 1.56 \\
\hline 14 & Middle of page drawing & 2 & 1.56 \\
\hline 15 & More than five fingers & 2 & 1.56 \\
\hline 16 & Pressure & 14 & 11 \\
\hline 17 & Shoulders squared & 9 & 7 \\
\hline 18 & Straight Lines & 22 & 17 \\
\hline 19 & Strokes away from subject & 2 & 1.56 \\
\hline 20 & Teeth well-defined & 4 & 3 \\
\hline 21 & Large figure shifted to left & 1 & 0.78 \\
\hline 22 & Chin Enlarged & 5 & 4 \\
\hline 23 & Spear Fingers & 6 & 4.7 \\
\hline 24 & Hands Powerful & 0 & 0 \\
\hline & & & \\
\hline & & & \\
\hline & & & \\
\hline
\end{tabular}




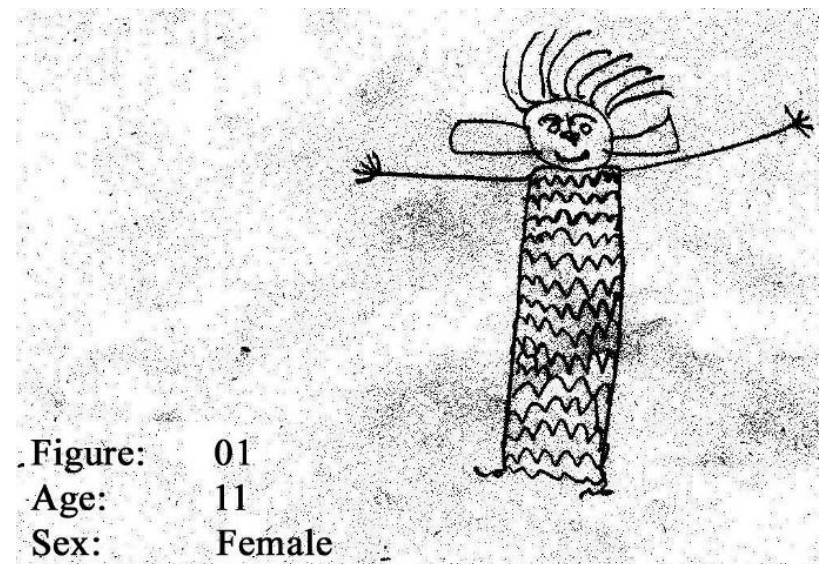

EI: 2

-Long Arms

-Straight lines
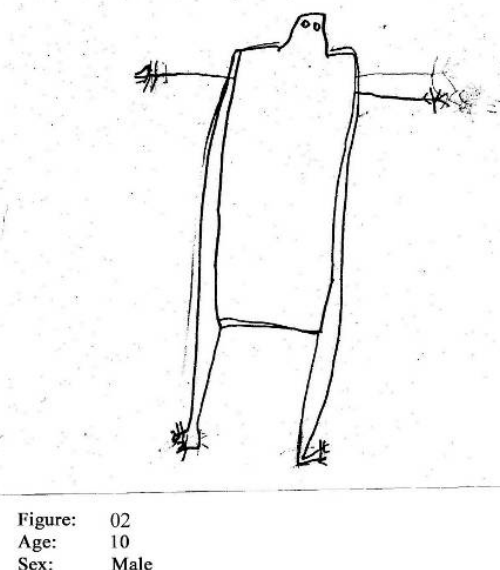

Sex: $\quad$ Male

EI: 4

-Shoulders Squared

-Pressure

-More than Five fingers
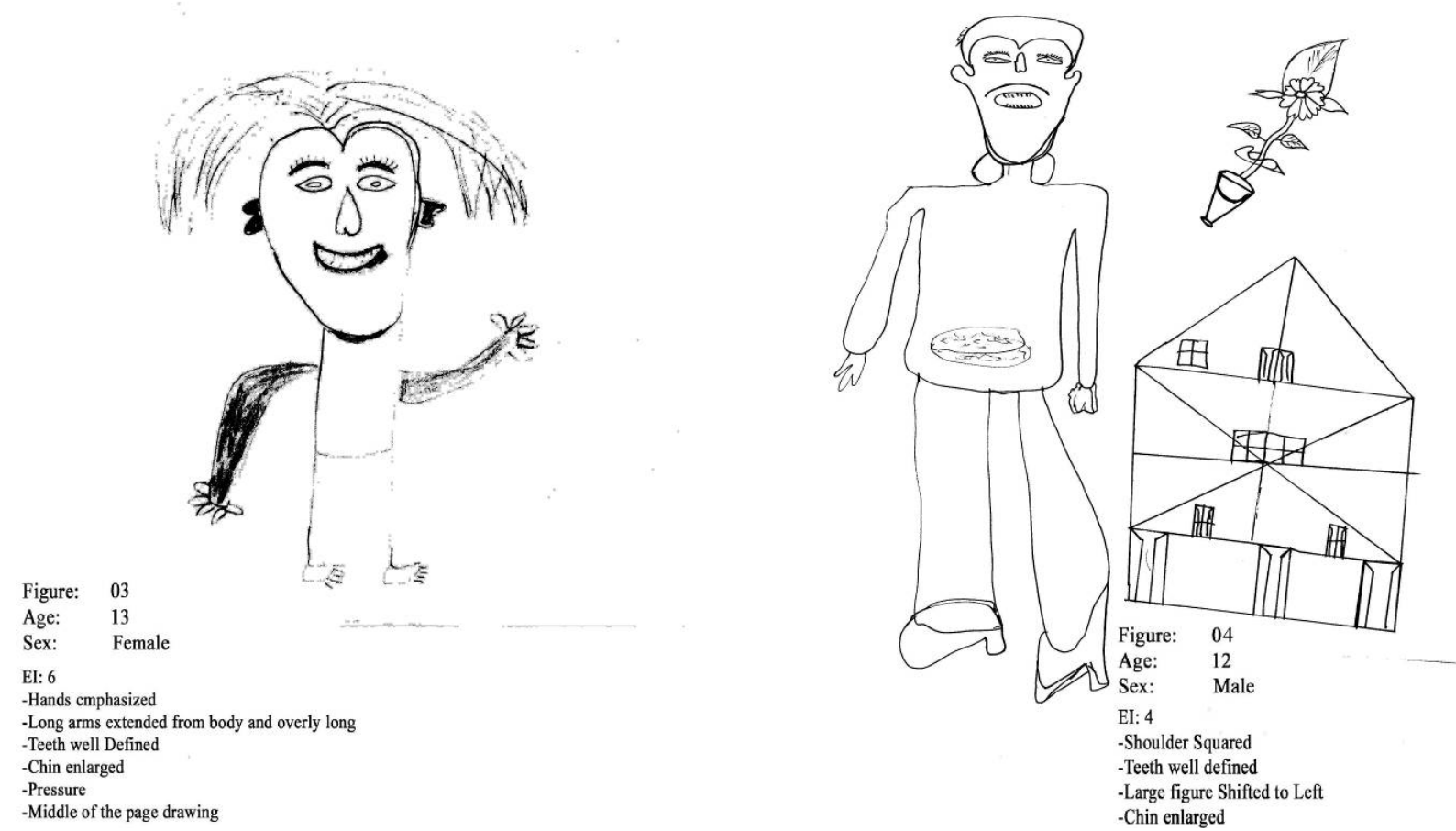

There is a variety of responses among males and females with $17 \%$ and $15 \%$ responses respectively revealing a straight line. The males reported more pressure at $11 \%$ while $3 \%$ of females drew pressure. Around $9.4 \%$ males drew claw fingers as compared to $5 \%$ females. Angular body and shoulders squared (see fig 05) were drawn by $7 \%$ boys while $5.5 \%$ shaded the drawing heavily (see fig 06) while no drawing among the females was shaded heavily. 


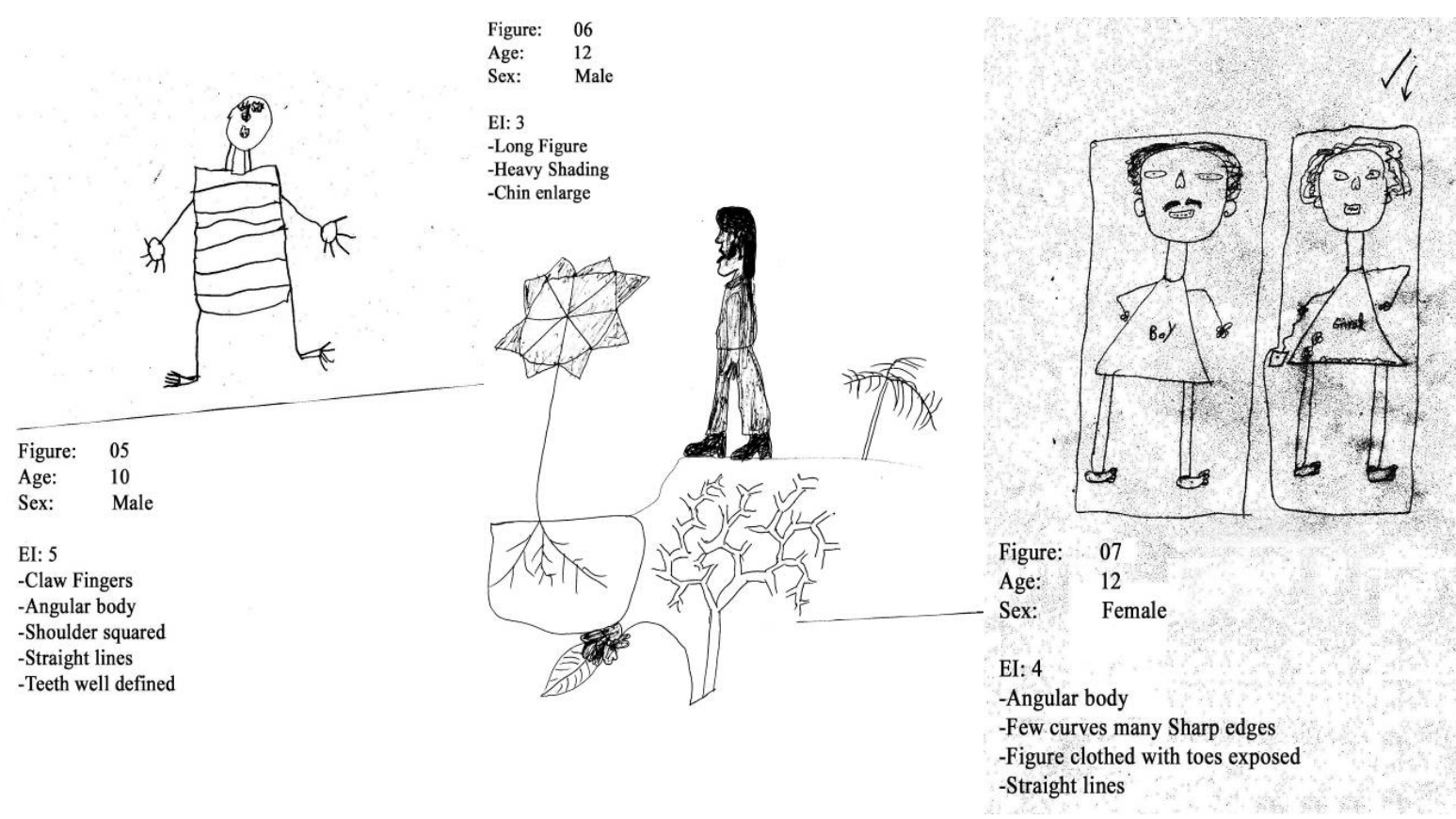

Among the female students $10 \%$ drew long arms and $9 \%$ drew figures that were clothed with toes exposed. $8.16 \%$ drew few curves with a figure having many sharp edges and well-defined teeth (see fig 07 ) while $3 \%$ of males drew it respectively. $6 \%$ emphasized eyes while 5\% drew claw fingers, emphasized hands and drew the figure in the middle of the page.

The results generally reveal the frequency of four indicators per drawing. The cut off point is three for emotional indicators (perdrawing) in Pakistan as suggested in study conducted by Hasan \& Ahmad (1990) utilizing the Koppitz (1969) method, the same cut off point was used here to interpret the drawings for emotional indicators.

The results shown in Table No 3 clarifies that signific ant differences were observed for the frequency of occurrence of emotional indicators for aggression between genders. Chi square analysis was conducted to compare males and females for the frequency of occurrence of emotional indicators, findings reflect significant difference in frequency of occurrence of indicators related to aggression between both the genders with calc ulated $X^{2}=4.37, p<05$.

However, there was no significant difference observed with the reference to the content of emotional ind ic ators between boys and girls. 
Table 3: Showing difference in the chi square values for frequency of occurrence of emotional indicators for aggression in both the genders

\begin{tabular}{|l|l|l|l|l|}
\hline $\begin{array}{l}\text { Emotional ind ic ators } \\
\text { for aggression }\end{array}$ & $\mathrm{X}^{2}$ & $\mathrm{~N}$ & $\mathrm{df}$ & $\begin{array}{l}\text { Level of } \\
\text { signific ance }\end{array}$ \\
\hline $\begin{array}{l}\text { All } 24 \\
\text { indic a tors }\end{array}$ & 4.37 & 75 & 1 & $\mathrm{p}<05$ \\
\hline
\end{tabular}

Table 4: Showing frequency of emotional ind ic ators for aggression in each drawing ${ }^{1}$

\begin{tabular}{|l|l|l|l|l|l|}
\hline $\begin{array}{l}\text { Emotional } \\
\text { indic ators } \\
\text { for aggression }\end{array}$ & $\begin{array}{l}\text { Drawings } \\
\text { with one or } \\
\text { no indic a tors }\end{array}$ & $\begin{array}{l}\text { Drawings } \\
\text { with two } \\
\text { indic ators }\end{array}$ & $\begin{array}{l}\text { Drawings } \\
\text { with three } \\
\text { indicators }\end{array}$ & $\begin{array}{l}\text { Drawings with } \\
\text { four or more } \\
\text { indicators }\end{array}$ & Total \\
\hline boys & 09 & 07 & 12 & 16 & 12 \\
\hline girls & 02 & 07 & 10 & 28 & 31 \\
\hline total & 11 & 14 & 22 & 75 \\
\hline $\begin{array}{l}\text { Drawings } \\
\text { classified as }\end{array}$ & $\begin{array}{l}\text { Showing } \\
\text { low } \\
\text { aggressive } \\
\text { tendencies }\end{array}$ & $\begin{array}{l}\text { Showing } \\
\text { average } \\
\text { aggressive } \\
\text { tendencies }\end{array}$ & $\begin{array}{l}\text { Showing } \\
\text { high } \\
\text { aggressive } \\
\text { tendencies }\end{array}$ & $\begin{array}{l}\text { Showing } \\
\text { very high } \\
\text { aggressive } \\
\text { tendencies }\end{array}$ & \\
\hline
\end{tabular}

The results shown in Table No 4 indicate that out of 75 drawings 11 drawings show one or no emotional indicator for aggression per drawing (classified as drawings showing low aggressive tendencies), 14 drawings show two emotional ind ic ators for aggression per drawing (classified as drawings showing average aggressive tendencies), 22 drawings show at least three emotional indicators for aggression per drawing (classified as drawings showing high aggressive tendencies) and 28 drawings show four or more than four emotional indicators for per drawing (classified as drawings showing very high aggressive tendencies). Therefore, on the basis of the results shown in Table No 4 it may be concluded that out of 75 children 50 children could be diagnosed as showing aggressive tendencies through their drawings.

${ }^{1}$ Classification is based on the cut off point identified for Emotional Indicators and noms established for HFD test in Pakistan by Hasan \& Ahmad (1990) utilizing Koppitz (1969) 


\section{Disc ussion}

The results displayed in Table 1 and 2 indicate the presence of aggressive tendencies among these children with straight lines as the most frequently occ uring indicator among both genders. The presence of aggressive indicators in these drawings thus verifies the association of reactive aggression indicators in the drawings of children with the history of trauma. The impact of environment and natural disasters is clearly seen among these children as their dra wings revealed their anger. Emotional Indic ators, long ams, powerful hands as well as teeth, occurred signific a ntly more often on the HFDs of the aggressive children than on the drawings of the shy children. These three items seem to reflect aggressiveness and acting out behavior (Koppitz, 1969). Furthermore, Machover (1949) also found emotional indic ators of power hand, hands overlong and extended, heavy pressure, among children who have aggressive tendencies.

Hammer (1963) found teeth well defined as an emotional indicator among children having aggressive tendencies. Moreover, presence of teeth might indicate not only oral aggression but also sadistic tendencies teeth seem to be a valid indicator for measurement of aggression by human figure drawing. Teeth occurred most often on the records of the overtly aggressive children, it may also be concluded that teeth a re sign of aggressiveness and not only of oral aggression (Kopitz , 1969).

The findings of the present research reconfims the presence of similar emotional indic ator related to aggression (e.g. pressure, teeth, long ams or ams extended, claw fingers) in the drawings of Pakista ni youth with the history of trauma which gives the clue for aggressive tendencies in these children. This confims that these indicators have good interpretive value and are valid emotional indicators for mea surement of aggressive tendencies on Human Figure Drawings test for Pakista ni children as well. However, it is interesting to note here that "straight line" as an emotional indicator has more interpretive value for measurement of aggressive tendencies in the drawing of Pakista ni child ren with the history of trauma.

The results clearly indic ate the importance of HFD as a tool in assessing for signs of aggression and other behavioral symptoms. These drawings exhibit controlled, uncontrollable, repressed, passive anger, which can further be taken in account when helping these children.

When males and females were compared for the frequency of occurrence of aggressive emotional indicators they seem to signific a ntly differ as indicated in Table 
No 3, with high frequency of males associated with most of the emotional indicators for aggression. Thus it becomes evident that there is a significant difference observed in drawing of both the genders with regard to expression of aggression. This may be because the cultural noms and values with relevance to expression of aggression for both the genders differ in Pakistan (Hasan \& Ahmad, 1990). The results shown in Table No 4 indicates that out of 75 drawings 11 drawings show one low aggressive tendencies (with one or no emotional indicators for aggression per drawing ), 14 drawings show average aggressive tendencies (with two emotional ind ic a tors for a ggression per drawing), 22 drawings show high aggressive tendencies (with three emotional indicators for aggression per drawing) and 28 drawings show very high aggressive tendencies (with four or more than four emotional indicators for aggression perdrawing). Thus in the light of the findings it may be concluded that out of 75 children 50 children could be diagnosed as showing considerable aggressive tendencies through their drawings. The findings confim the expectation about occurrence of large number of emotional indicators related to aggression in the drawings of children with the history of tra uma.

These research findings have implications for post disaster mental health services. Traditionally researchers focus on the intemalized problems such as anxiety, depression and post traumatic stress disorder symptoms. Very little attention is paid to post disaster extemalized problems such as aggression. Specific types of aggression responses, particularly those that involve poorly regulated emotion (i.e. reactive aggression), have been found to be associated with history of trauma (Marsee, 2008) and thus may be especially common following a traumatic event such as an earthquake. Marsee (2008) proposed a theoretical model illustrating a potential pathway to reactive aggression through exposure to traumatic event. The findings of the current study support the association between exposure to tra umatic event and presence of aggression indicators in the drawings of children with the history of trauma. However, the association between exposure to trauma and reactive aggressive behavior via poorly regulated emotions couldn't be confirmed by findings of the present study as data about the actual levels of aggressive behavior of children could not obtained through, parents, teachers or observation, due to language bamier, lack or time and resources. Therefore, this is one limitation of this study and in future this information could be added to validate the children trauma through other means as well. This study was also limited on participants, number of participants could be increased in future study so that the difference between the content of aggressive indicators may also be studied with the reference to both the genders and this would be another very interesting area to explore. 
Finally on the basis of the findings of the present study it can be safely concluded that drawing is an powerful tool to measure aggressive tendencies in youth who have diffic ulty expressing their feelings in words, or may have problems expressing themselves either due to language bariers or due to any other inhibitions related to cultural norms for both the genders.

Furthemore, once aggressive tendencies are screened out in children though frequency of occurrence of emotional indicators for aggression in drawings, the same technique may be used as a therapeutic tool for catharsis and providing an outlet for the children in stress or with a history of trauma. Drawing could also be used as a medium of choice by children to express and regulated their emotion (e.g anger). Brenkman (1999) found that Art therapy is becoming a popular tool to work with children. The findings of this study do not only support the use of the Human Figure Drawing test as diagnostic tool for identifying aggressive tendencies in Pakistani children with the history of trauma, but suggests that the test may also act as a preventive measure, helping to screen out aggressive tendencies through aggression indicators in drawings and by this to provide timely support to highly vulnerable youth with history of trauma.

\section{References}

Akhtar, S., Anwar, T., Khan, N.A., Noshab, F., Sadiq, M., Bashir, S. and Sarwar, N. (2006), Pakistan 2005 Earthquake: An Assessment of Impoverishment Risks, (CRPRID Research Team) Centre for Research on Poverty Reduction and Income Distribution, www.crprid.org.

American Psychiatric Association,(2000). Diagnostic and Statistical Manual of Mental Disorders, Fourth Edition, Text Revision. 1000 Wilson Boulevard. Arlington, V A.

Arieti, S., (1974). Interpretations of Sc hizo phrenia. Ba sic Books, Inc., New York.

Baldwin, I. T. The Head Body Ratio in Human Figure Drawings of Schizophrenic and Nomal Adults. J. Proj, Tech. \& Pers. Asses., 28:393-396.

Bano, M., Irshad, E., Ahmed, R. (2004), Emotional Indicators of Aggression in Human Figure Drawing of Afghan Refugee Children, Pakistan J oumal of Psychology, J une 2004, 35, 51- 65. 
Brenkman, J. (1999). Separation and creativity: Redefining the lost language of childhood. New York: Other Press.

Daum, J .M., (1983). Emotional Indic ators in Drawings of Aggressive or Withdrawn Male Delinquent. J oumal of Persona lity Assessment. Vol. 47, No. 3, 243-249.

Dennis, W., (1966). Goodengouh Scores, Art Experience, and Modemization. J oumal of Social Psychology. Vol 68, 211-228.

DesLauriers, A ., Halpem, F. (1947). Psychological Test in Childhood Schizophrenia. Americ an J oumal of Orthopsychiarty. Vol 17, 57-69.

DiLeo, J . H., (1973). Children Dra wings as Dia gnostic Aids. Bumner/Mazel. New York.

Gardner, G. (1971). Aggression and violence-the enemies of precision leaming in children. Americ an J oumal of Psychiatry, 128, 445-450.

Gardiner, H.W., (1969). A Cross Cultural Comparison of Hostility in Children's Drawing. J oumal of Social Psychology. 79(2) , 261-263.

Gilbert, J. (1980), Interpreting Psychological Test Data, Volume II, 13-63, Nostrand Reinhold Company, NY.

G lazer, H.R. (1999). Children and play in the Holocaust. J oumal of Huma nistic Counseling, Education and Development, 37, 194-200.

Gonzales, E., (1982). A Cross Cultural Comparison of the Developmental Items of Five Ethnic Groups in Southwest. J oumal of Persona lity Assessemnt.

Ha mmer,E..F., (1973). C linic al Applic ation of Projec tive Dra wings. Spring field, Thomas.

Hasan, E., Ahmad, F.Z, (1990). Standardization of Draw Person Test in Pakistan. Institute of C linic al Psychology, University of Ka ra chi, Pakistan.

Hussain, A, (2005). Manual for Treatment of Traumatised Children and Adolescents. University of Missouni, School of Medicine, N 119, Health Sciences Center, One Hospital Drive, Columbia. Misso uni 65212 U.S.A.

Klopfer, W. G., \& Taulbee, E. S. (1976). Projective tests: Annual Review of Psychology. Vol 27 1976, 543-567. 
Koppitz, E.M. (1969), Psychological Evaluation of Children's Human Figure Drawings, Grune \& Stratton, N.Y.

Lazarus.P.J .,J imerson, S.R., Brock, S.E. (2002). Natural disaster. In S.E. Brock, P.J Lazarus, \& S. R J imerson (Eds), Best practices in school crisis prevention and intervention (pp. 435450). Bethesda, MD: National Assoc iation of School Psychologists.

Lindzey, G., (1961). Projective Techniques and Cross Cultural Research. Appleton Century Crofts, Inc. New York.

Lowenfield, V., (1947). Creative and Mental Growth, In Fax, T. J and Thomas G.V (1990) Child ren's drawings of an anxiety elic iting topic. Effects on the size of the drawing. British J oumal of Clinical Psychology, 29, 71-78.

Machover, K., (1949). Personality Projection in the Drawing of the Human Figure. C.C. Thomas. Spring field, III

Marsee, M. A., (2008), Reactive Aggression and Posttruamatic Stress in Adolescents Affected by Huric ane Katrina. J oumal of Clinical Child and Adolescent Psychology, v37 n7 p 519-529, J uly. http://www.tandf.co.uk/joumals/defualt.html

Myers, B. (2002). Helping children cope with disaster. Wa shington, DC: National Institute of Mental Health Association.

Naumberg, M. (1958). Art Therapy : Its sc ope and function in the clinical application of projec tive drawings. New York: Gume and Stratton as cited by J acobs.

Parson, E. I, (1994). Post-tra umatic stress and coping in an inner c ity child: Tra umatogenic witnessing of inter-parental violence and murder. Psychoanalytic Study of the Child, SO.

Stronach-Buschel, B. (1990). Art therapy for children: Post-traumatic stress disorder in children. Americ an J oumal of Art Therapy, 29, 48-52.

Sundberg , N.D., (1976). The Practice of Psychological Testing in Clinic al Servic es in the United States. In the Clinical Psychologists. (Eds) B. Lubin \& E.E. Levitt. Aldine Publishing Co. Schage, 155-162.

Zafran, A., \& Zawitz, D. (1997). Gender \& Sex Roles. www. About com. 
About the authors:

Dr. Zainab F. Zadeh is currently the Director of the Institute of Professional Psychology at Bahria University, Karachi Campus, Pakistan. She obtained her doctorate from Bahria University in the year 2004. She has published articles in the areas of marriage systems in Pakistan and their socio-economic dynamics, adolescents and self concepts, qualitative studies with delusional and psychotic patients. Her published articles also include topics like emotional intelligence, stress at work and gender differences a long with a nalysis of play therapy sessions. She is a member of APA and APT. She also holds a Diploma in Humanistic Counselling from the London School of Counselling.

E-mail: zainfz@yahoo.com

Sonia Mairaj Malik is currently a Lecturer at the Institute of Professional Psychology at Bahria University, Karachi Campus, Pakistan. She completed her Masters in Clinical Psychology and is a PhD candidate at the Institute. She teaches at both Graduate and Postgraduate levels. 